\title{
Comparison between cell culture and serology for detecting Chlamydia trachomatis in women seeking abortion
}

\author{
P A CSÁNGÓ,* B SAROV, $\dagger$ H SCHIØTZ, $\ddagger$ I SAROVף
}

From the Departments of *Microbiology and Gynaecology, Vest-Agder Central Hospital, Kristiansand, Norway, and the + Epidemiology and $\llbracket$ Virology Units, Faculty of Health Sciences, Ben Gurion University of the Negev, Beer Sheva, Israel

SUMMARY The efficiency of an immunoperoxidase serological assay and culture of Chlamydia trachomatis were compared in 127 women seeking first trimester abortion. Serum IgG and IgA antibodies specific for $C$ trachomatis were detected by a single serovar (L2) inclusion immunoperoxidase assay (IPA). Eighty (63\%) women were seropositive for chlamydial IgG and 31 (24\%) for IgA antibodies. $C$ trachomatis was isolated from 21 of $127(17 \%)$ women. Twenty of the 80 women $(25 \%)$ seropositive for specific IgG antibodies and one of $47(2 \%)$ patients without these antibodies were culture positive $(\mathrm{p}<0.001)$. Compared with isolation, chlamydial antibodies at a titre of $\geqslant 16$ showed high sensitivity and negative predictive value (95\% and $98 \%$, respectively), but low specificity and efficiency (43\% and 52\%, respectively). Chlamydial IgA antibodies at a titre of $\geqslant 8$ showed low sensitivity $(52 \%)$, but a higher specificity, negative predictive value, and efficiency of $81 \%, 90 \%$, and $76 \%$, respectively. $C$ trachomatis IgG antibodies at a titre of 16 as determined by IPA can be used as an efficient negative exclusion marker for active chlamydial infection in screening women seeking abortion.

Postabortal salpingitis may complicate postoperative recovery in about $20 \%$ of women infected with $C$ trachomatis.' To avoid this complication screening for $C$ trachomatis by direct immunofluorescence and culture isolation has recently gained wider application for women wanting an abortion. Although culture is the standard reference method, it is costly, time consuming, and requires considerable experience. The results may also arrive too late and therefore be of little help in deciding on appropriate management. Direct detection methods are speedier, but they, too, require expensive equipment, skill, and may be less sensitive than culture. ${ }^{2}$ In this study we compared the efficiency of a new and sensitive serological method with the standard cell culture. The results of cell culture were correlated with serology for specific chlamydial IgG and IgA antibodies by the single serovar (L2) IPA.

\section{Patients and methods}

One hundred and twenty seven women presenting for first trimester abortion were included in the study. The

Accepted for publication 14 July 1987 study population, age distribution, sampling technique, transport and culture of $C$ trachomatis have been described elsewhere.'

The detection of IgG and IgA antibodies specific for $C$ trachomatis was carried out by a single serovar (L2) immunoperoxidase assay (IPA, "Ipazyme Chlamydia", Savyon Diagnostics Ltd, Beer Sheva, Israel), according to a previously described method. ${ }^{3}$ Titres of 16 and 8 were regarded as seropositive in the IgG and IgA tests, respectively.

The analysis was based on Bayes' theorem, ${ }^{4}$ further defined by Galen and Gambino.' Sensitivity was defined as the percentage of seropositive tests in patients with $C$ trachomatis positive cultures and specificity as the percentage of seronegative tests in patients with negative cultures. The positive predictive value was defined as the probability that a patient who had a positive serological test actually yielded $C$ trachomatis on culture. The negative predictive value was the probability that a seronegative patient produced a negative culture. With data on test sensitivity, specificity, and the prevalence of $C$ trachomatis isolates among patients, the positive predictive value can readily be determined from the equation, or in terms of numbers of true positive and false positive results: 
Predictive value of positive results:

sensitivity $\times$ prevalence

sensitivity $\times$ prevalence $+(1-$ specificity $) \times(1-$ prevalence $)$

or in terms of true positive and false positive results:

Predictive value of positive results: $\frac{\text { true positive }}{\text { true positive }+ \text { false positive }}$

A similar equation gives the figure for the predictive value of negative results. Efficiency was determined as the percentage of patients who were correctly classified using the formula:

(Prevalence $\times$ Sensitivity $+1-$ Prevalence) $\times$ Specificity) $\times 100$,

otherwise given by the formulas:

$$
\frac{\text { true positive }+ \text { true negative }}{\text { the size of population screened }} \times 100
$$

$\chi^{2}$ analysis was used to test the association between the two screening tests.

\section{Results}

C trachomatis was isolated from 21 of $127(17 \%)$ women. Table 1 shows that $63 \%$ of the patients were seropositive by the IPA test, specific for chlamydial IgG. $C$ trachomatis was isolated from 20 of the 80 seropositive women and one of the 47 seronegative women. This difference was significant $(p<0.01)$.

Table 2 shows the results of specific IgA detection compared with culture. $C$ trachomatis was isolated from 11 of the 31 seropositive women and 10 of the 96 seronegative women. This difference was significant $(\mathrm{p}<0.01)$. The prevalence of chlamydial IgA was $24 \%$ at a $1 / 8$ dilution of serum. All sera positive for IgA were also seropositive for IgG (titre of $\geqslant 16$ ). Of those women with antibodies specific for both IgG and

Table 1 Determination of chlamydial $\lg G$ by immunoperoxidase assay compared with results of culture

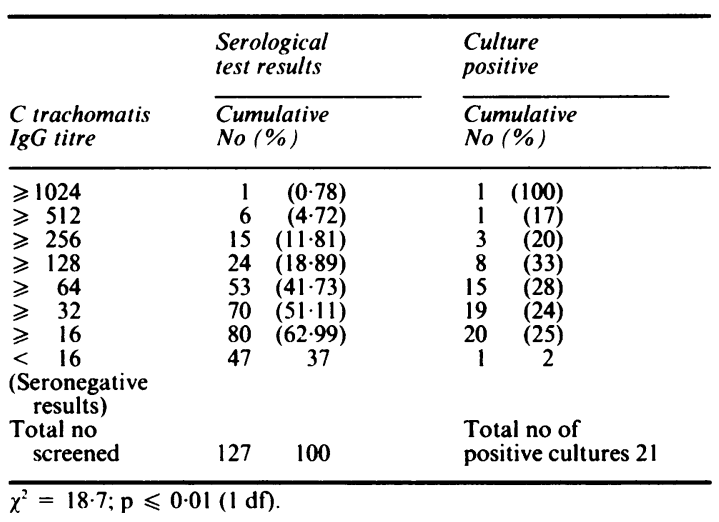

Table 2 Determination of chlamydial IgA by immunoperoxidase assay compared with results of culture

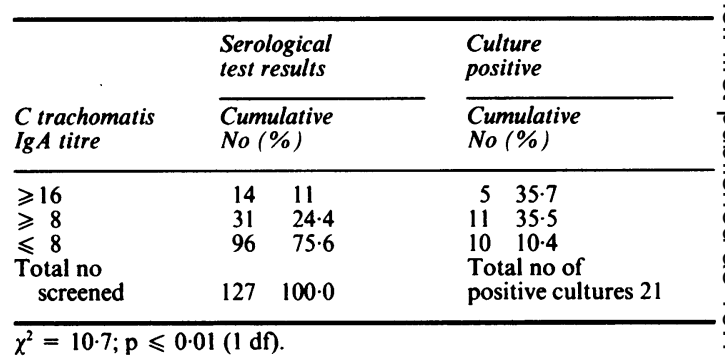

IgA, 13 were culture positive and 21 were culture $\stackrel{\circ}{\circ}$ negative. Of the 21 culture positive patients, one had용 no IgG specific antibodies and eight no chlamydial $A$ IgA antibody.

The validity of the IgG and $\operatorname{IgA}$ tests was evaluated by results of $C$ trachomatis culture and the sensitivity and specificity of the tests were compared at different $\triangle$ titres (table 3). The chlamydial IgG test was more $\vec{c}$ sensitive at lower titres and more specific at higher $\stackrel{\varrho}{丂}$ titres. The IgA test was more specific, but less sensitive compared with the IgG test. The IgA test was the most $₹$ efficient at the titre of $\geqslant 16(80 \%)$. The intermediate $\overrightarrow{0}$ efficiency for the IgG test was $65 \%$ (at a titre of $\geqslant 64$ ) $\infty$ and the IgG test was least efficient at a dilution of $\geqslant 16$.

\section{Discussion}

We have shown that the IPA test for chlamydial IgG $\stackrel{\circ}{\odot}$ antibodies at a titre of 16 had a higher sensitivity and $\triangle$ negative predictive value ( $95 \%$ and $98 \%$, respectively) compared with $C$ trachomatis isolation, but a relatively low positive predictive value, specificity, and efficiency $(25 \%, 43 \%$, and $52 \%$, respectively) (table 3$)$. Our results agree with those of other similar studies ${ }^{16-8}$ and on different groups of women with cervical chlamydial infection. ${ }^{9-13}$ These show that chlamydial 3 serum IgG antibodies are more common in culture positive compared with culture negative patients.

Previous studies have suggested that the presence of $\mathrm{O}$ chlamydial serum IgA antibodies can be used as a potential marker of active or persistent infection in various conditions - salpingitis, infertility, nongonococcal urethritis, and epididymitis. ${ }^{3141520}$ In our $\widetilde{N}$ study chlamydial IgA showed low sensitivity and a N negative predictive value $(52 \%$ and $90 \%$, respec- N tively), but a higher specificity and efficiency $(81 \%$ and $\sigma$ $76 \%$, respectively) compared with cell culture. The sensitivity at a titre of $\geqslant 8$ was only $52 \%$, which means $?$ that this type of screening would give a higher proportion of false negative results compared with culture, and it would therefore only be of advantage in one out of two women. Serum IgA might not always $\overrightarrow{\mathbb{D}}$ indicate the presence of $C$ trachomatis in the cervix, 
Table 3 Percentage evaluation of immunoperoxidase test at various titres of IgG and IgA antibodies compared with culture results

\begin{tabular}{|c|c|c|c|c|c|}
\hline Test evaluation & Sensitivity & Specificity & $\begin{array}{l}\text { Positive } \\
\text { predictive value }\end{array}$ & $\begin{array}{l}\text { Negative } \\
\text { predictive value }\end{array}$ & Efficiency \\
\hline $\begin{array}{l}\text { Immunoperoxidase IgG titre: } \\
\geqslant 16 \\
\geqslant 32 \\
\geqslant 64 \\
\geqslant 128 \\
\geqslant 256\end{array}$ & $\begin{array}{l}95 \\
90 \\
71 \\
38 \\
14\end{array}$ & $\begin{array}{l}43 \\
52 \\
64 \\
85 \\
87\end{array}$ & $\begin{array}{l}25 \\
27 \\
28 \\
33 \\
20\end{array}$ & $\begin{array}{l}98 \\
96 \\
92 \\
87 \\
84\end{array}$ & $\begin{array}{l}52 \\
58 \\
65 \\
77 \\
76\end{array}$ \\
\hline $\begin{array}{l}\text { Immunoperoxidase IgA titre: } \\
\geqslant 8 \\
\geqslant 16\end{array}$ & $\begin{array}{l}52 \\
24\end{array}$ & $\begin{array}{l}81 \\
92\end{array}$ & $\begin{array}{l}35 \\
36\end{array}$ & $\begin{array}{l}90 \\
86\end{array}$ & $\begin{array}{l}76 \\
80\end{array}$ \\
\hline
\end{tabular}

possibly because of serum derived $\operatorname{IgA}$ antibody excreted in the cervix. ${ }^{1213}$ Such local antibodies have been shown to regulate or suppress the cervical shedding of $C$ trachomatis. ${ }^{16}$ Chlamydial IgA antibodies in cervical secretions show a closer correlation with cervical infection, ${ }^{7-11}$ although an inverse correlation was shown by Brunham et al, ${ }^{16}$ who also showed that antibodies to certain chlamydial antigens protect against acute salpingitis. ${ }^{17}$

Although chlamydial IgA serum antibodies may indicate continuing antigenic stimulation, ${ }^{3}$ "I is our patients were asymptomatic women, in whom the presence of serum antibodies could not be regarded as an effective marker of a mild mucosal infection. Thus for this group of patients, the IgG test gave a higher sensitivity and lower false negative rate and should therefore be regarded as a better screening test than the IgA test.

The specificity of the IgG test was only $43 \%$. This can be explained as serology was evaluated by isolating $C$ trachomatis from the genital tract. Chlamydial IgG antibodies detected by IPA, determined by $C$ trachomatis (L2) infected cells as antigen, have a broad reactivity. Specific IgG antibodies may indicate ongoing or past chlamydial infection in sites other than the genitourinary tract. ${ }^{18}$ This may explain the discrepancy in the detection rates between serology and culture. The development of a serological technique of comparable sensitivity, which detects only genital strains of $C$ trachomatis, could be valuable. Furthermore, the isolation of $C$ trachomatis in cell culture is less than $100 \%$ sensitive, although it is thought to be the "golden standard" by which other methods are evaluated. In active infections, therefore, IgG may be present and yet cell culture may be negative. According to Robertson et $a l,{ }^{21}$ an indirect fluorescence test with $C$ trachomatis $\mathrm{L} 2$ as antigen showed that there were almost twice as many seropositive results among women seeking abortion compared with women who used barrier contraception and did not become pregnant.
Chlamydial infections are treatable, but the complications of postoperative chlamydial disease can be serious. ${ }^{16722}$ Chlamydial salpingitis and endometritis with subsequent infertility can be prevented by early detection and treatment. Rapid diagnosis can be facilitated by the IPA technique which can be read with a light microscope and easily performed in every laboratory. Its high sensitivity, negative predictive value, speed and simplicity make it an adjunct to existing diagnostic procedures. The test can therefore be used to screen women who want an abortion and can thus prevent unnecessary use of antibiotics in seronegative women. The use of preoperative antibiotics without screening could be a simpler and less expensive approach in a population with a high incidence of chlamydial infections, but objections could be raised against treatment without screening in populations with a low incidence as many patients would be treated unnecessarily.

Nettleman et al ${ }^{19}$ suggest that the most cost effective approach is to serotest all patients and treat those who are seropositive. Deciding whom to treat would then be based on relative risk and not direct evidence of infection. Because of its high sensitivity and negative predictive value, serology would effectively exclude women not requiring direct testing and at the same time it could lead to a more careful follow up of the seropositive women. The advantages and disadvantages of the serological testing compared with those of culture have to be weighed against each other.

If direct detection of $C$ trachomatis is to be widely adopted then the development of less complex, more sensitive, and rapid techniques is necessary to decide which seropositive patients harbour $C$ trachomatis in their genital secretions.

We thank Garletta Jagars for technical help and Morag Mae Taylor Upsahl for useful discussions.

This study was supported in part by the Middle East Eye Research Institute (MEERI), Apothekernes Laboratorium A/S, and the Royal Norwegian Ministry of Foreign Affairs. 
References

I Schiфtz H, Csángó PA. A prospective study of Chlamydia trachomatis in first trimester abortion. Ann Clin Res 1985;17:60-3.

2 Ridgway GL. The laboratory diagnosis of chlamydial infection. In: Oriel D, Ridgway D, Schachter J, Taylor-Robinson D, Ward $\mathrm{M}$, eds. Chlamydial infections. Cambridge: Cambridge University Press, 1986:539-49.

3 Piura B, Sarov I, Sarov B, Kleinman D, Chaim W, Insler V. Serum IgG and IgA antibodies for Chlamydia trachomatis in salpingitis patients as determined by the immunoperoxidase assay. Eur J Epidemiol 1985;1:110-6.

4 Bayes T. An assay towards solving a problem in the doctrine of chance. Philos Trans R Soc Lond (Biol) 1763;53:370-418.

5 Galen RS, Gambino SR. Beyond normality: the predictive value and efficiency of medical diagnoses. New York: John Wiley, 1975.

6 Qvigstad E, Skaug K, Jerve F, Fylling P, Ulstrup JC. Pelvic inflammatory disease associated with Chlamydia trachomatis infection after therapeutic abortion. British Journal of Venereal Disease 1983;59:189-92.

7 Osser S, Pearson K. Postabortal pelvic infection associated with Chlamydia trachomatis and the influence of humoral immunity. Am J Obstet Gynecol 1984;150:699-703.

8 Qyigstad E, Skaug K, Jerve F, Vik ISS, Ulstrup JC. Therapeutic abortion and Chlamydia trachomatis infection. British Journal of Venereal Disease 1982;58:182-3.

9 Treharne JD, Darougar S, Simmons PD, Thin RN. Rapid diagnosis of chlamydial infection of the cervix. British Journal of Venereal Disease 1978;54:403-8.

10 Schachter J, Cles L, Rose R, Hines P. Failure of serology in diagnosing chlamydial infections of the female genital tract. $J$ Clin Microbiol 1979;10:647-9.

11 Terho P, Meurman O. Chamydial serum IgG, IgA and local IgA antibodies in patients with genital-tract infections measured by solid-phase radioimmunoassay. J Med Microbiol 1981; 14:77-87.

12 Richmond SJ, Milne D, Hilton AL, Caul EO. Antibodies to Chlamydia trachomatis in cervicovaginal secretions: relations to serum antibodies and current chlamydial infection. Sex Transm Dis 1981;7:11-5.

13 Gump DW, Gibson M. Antibodies to Chlamydia trachomatis in cervical secretions and serum: effect of blood on such secretions. Fertil Steril 1985;43:814-5.
14 Sarov I, Sarov B, Hanuka N, Glasner M, Kaneti J. The significance of serum specific IgA antibodies in diagnosis of active Chlamydia trachomatis infections. In: Oriel D, Ridgway D, Schachter J, Taylor-Robinson D, Ward M, eds. Chlamydial infections. Cambridge: Cambridge University Press, 1986;566-9.

15 Cevenini R, Sarov I, Rumpianesi F, Donati M, Melega C, Varotti C, La Placa M. Serum specific IgA antibody to Chlamydia trachomatis in patients with chlamydial infections detected by ELISA and immunofluorescence test. $J$ Clin Pathol 1984;37:686-91.

16 Brunham RC, Kuo C-C, Cles L, Holmes KK. Correlation of host immune responses with quantitative recovery of Chlamydia of trachomatis from the human endocervix. Infect Immun 1983;39:1491-4.

17 Brunham RC, Maclean I, McDowell J, Peeling R. Chlamydia trachomatis antigen specific serum antibodies among women who did and did not develop acute salpingitis following abortion. In: Oriel D, Ridgway D, Schachter J, Taylor-Robinson $\mathrm{D}$, Ward $\mathrm{M}$, eds. Chlamydial infections. Cambridge: Cambridge University Press, 1986:221-4.

18 Forsey T, Stainsby K, Hoger PH, Ridgway GL, Darougar S, Fisher-Brugge U. Comparison of two immunofluorescence tests for detecting antibodies to $\mathrm{C}$. trachomatis. Eur $J$ Epidemiol 1986;2:163-4.

19 Nettleman MD, Jones RB, Roberts SD, Dittus RS. Cost-effectiveness of serology and cell culture for Chlamydia trachomatis in low prevalence women. In: Oriel D, Ridgway D, Schachter J, Taylor-Robinson D, Ward M, eds. Chlamydial infections. Cambridge: Cambridge University Press, 1986:204-8.

20 Sarov I, Kleinman D, Holcberg G, Potashnik G, Insler V, Cevenini R, Sarov B. Specific IgG and IgA antibodies to Chlamydia trachomatis in infertile women. Int $J$ Fertil 1986;31:193-7.

21 Robertson JN, Ward ME, Conway D, Caul EO. Chlamydial and gonococcal antibodies in sera of infertile women with tubal obstruction. J Clin Pathol 1987;40:377-83.

22 Barbacci MB, Spence RM, Kappus EW, Burkman RC, Rao L, Quinn TC. Postabortal endometritis and isolation of Chlamydia trachomatis. Obstet Gynecol 1986;68:686-90.

Requests for reprints to: Dr P A Csángó, Department of Microbiology, Vest-Agder Central Hospital, N-4604 Kristiansand S, Norway. 